\title{
Laser Cutting of Non-Metallic Material - PMMA
}

Rastislav Nigrovič, Jozef Meško

University of Žilina, Univerzitná 1, Department of Technological Engineering; rastislav.nigrovic@fstroj.uniza.sk, jozef.mesko@fstroj.uniza.sk

The presented article describes and characterizes laser cutting of PMMA, the impact of the laser beam on the PMMA material and compares it with a conventionally using cutting of plastic material - milling. In the experimental part is compare sample shown in Fig. 4 which was cutting by using a laser beam, milling and the sample which has been cut by laser but was modified by drying, which change properties of the material after cutting.

Keywords: laser cutting, milling, plastic materials, PMMA

\section{Acknowledgement}

Research presented in this paper was partially financially supported through realization of projects VEGA no. 1/0186/09 - ( V-13-013-00) - „Technological aspects of the laser cutting process, numerical modeling and simulation in terms of optimalization, improve the quality and efficiency of production processes „. Responsible investigator : prof. Jozef Meško, MSc., Ph.D.

\section{References}

[1] SILVFAST, W. T. (2004). Laser Fundamentals, Cambridge University Press, 666p. ISBN 0-521-83345-0.

[2] CARISTAN, L. C. (2004). Laser cutting guide for manufacturing. Dearborn, Michigan, USA: Society of Manufacturing Engineers, 452p. ISBN 0-87263-686-0.

[3] ŽMINDÁK, M., MEŠKO, J., PELAGIČ, Z., ZRAK, A. (2014). Finite element analysis of crack growth in pipelines. In: Manufacturing Technology: journal for science, research and production, Vol. 14, No. 1, s. 116-122. ISSN 1213-2489.

[4] SEJC, P., BIELAK, R., SVEC, P., ROSKO, M. (2006). Computer simulation of heat affected zone during MIG brazing of zinc-coated steel sheets. In: Kovové materiály. Metallic materials. Vol. 44, No. 4, pp.225-234. ISSN 0023-432X.

[5] KONAR, R., MICIAN, M., HLAVATY, I. (2014). Defect detection in pipelines during operation using Magnetic Flux Leakage and Phased Array ultrasonic method. In: Manufacturing technology, Vol. 14, No. 3, pp. $337-341$. J.E. Purkyne University, Ústi nad Labem. ISSN 1213-2489.

[6] KONAR, R., MICIAN, M. (2014). Non-destructive testing of welds in gas pipelines repairs with Phased Array ultrasonic technique. In: Manufacturing technology, Vol. 14, No. 1, pp. 42-47. J.E. Purkyne University, Ústi nad Labem. ISSN 1213-2489.

[7] MESKO, J., ZRAK, A., MULCZYK, K., TOFIL, S. (2014). Microstructure analysis of welded joints after laser welding. In: Manufacturing technology, Vol. 14. No. 3, pp. 355-359. 341. J.E. Purkyne University, Ústi nad Labem. ISSN 1213-2489.

[8] RADEK, N., MESKO, J., ZRAK, A. (2014). Technology of laser forming. In: Manufacturing technology, Vol. 14, No. 3, pp. 428-431. J.E. Purkyne University, Ústi nad Labem. ISSN 1213-2489.

[9] VRZGUlA, P., FATURIK, M., MICIAN, M. (2014). New inspection technologies for identification of failure in the material and welded joints for area gas industry. In: Manufacturing technology, Vol. 14, No. 3, pp. 487-492. J.E. Purkyne University, Ústi nad Labem. ISSN 1213-2489.

[10]PATEK, M., KONAR, R., SLADEK, A., RADEK, N. (2014). Non-destructive testing of split sleeve welds by the ultrasonic TOFD method. In: Manufacturing technology, Vol. 14, No. 3, pp. 403-407. J.E. Purkyne University, Ústi nad Labem. ISSN 1213-2489.

[11]LAGO, J., BOKUVKA, O., NOVY, F. (2015). The weld toe improvement of Domex 700 by laser remelting. In: 32nd Danubia-Adria symposium on advances in experimental mechanics, pp. 142-143. University of Žilina, Žilina. ISBN 978-80-554-1094-4.

[12]HUANG, Y., LIU, S., Yang, W., YU, Ch. (2010). Surface roughness analysis and improvement of PMMA-based microfluidic chip chambers by CO2 laser cutting. In: Applied surface science Vol. 256, pp. 1675-1678. Elsevier. ISSN 01694332.

[13] VAN KREVELEN, D.W. (2009). Properties of polymers, ISBN-9780080548197.

[14]EUROLASER.(2015).[online].2016,[cit.2016-02-01]. < http://www.eurolaser.com/cz/products/laser-systems-foracrylic/xl-1200-acrylic/ >. 